\title{
Variasi Genetik Mutan Anggrek Spathoglottis plicata Blume. Berdasarkan Marker ISSR
}

\section{Genetic Variations of Spathoglottis plicata Blume. Orchid Mutants Based on ISSR Markers}

\author{
Atra Romeida $^{*}$, Surjono Hadi Sutjahjo ${ }^{2}$, Agus Purwito ${ }^{2}$, Dewi Sukma ${ }^{2}$, dan Rustikawati ${ }^{1}$ \\ ${ }^{1}$ Fakultas Pertanian, Universitas Bengkulu, Jl. Raya Kandang Limun Bengkulu, Indonesia \\ ${ }^{2}$ Departemen Agronomi dan Hortikultura, Fakultas Pertanian, Institut Pertanian Bogor \\ (Bogor Agricultural University), Jl. Meranti, Kampus IPB Darmaga, Bogor 16680, Indonesia
}

Diterima 8 Maret 2012/Disetujui 11 Juli 2012

\begin{abstract}
Mutants of Spathoglottis plicata Blume were obtained from plants treated with Gamma Irradiation at 30-100 Gray. The mutants showed variations in the flower morphology. The objective of this experiment was to identify genetic variations of orchids $\underline{S}$. plicata and its mutants using inter-simple sequent repeat (ISSR) markers. The amplified product of 10 ISSR primers produced 360 bands and 71 ISSR of the loci (90.14\%) were polymorphic. The coefficient of similarity and principal component analysis produced five major groups with similarity coefficient of 0.68. The goodness of fit correlation matrix value reached 0.91. Therefore the ISSR is a good marker for identification of $\underline{S}$. plicata mutants.
\end{abstract}

Keywords: gamma irradiation, ISSR marker, mutant, orchid

\section{ABSTRAK}

Irradiasi sinar gamma menggunakan dosis antara 30-100 Gray telah menghasilkan beberapa mutan anggrek Spathoglottis plicata Blume. yang memiliki variasi morfologi bunga. Penelitian ini bertujuan untuk mengidentifikasi variasi genetik mutan anggrek $\underline{S}$. plicata menggunakan penanda ISSR. Produk dari 10 primer ISSR yang digunakan dalam percobaan ini telah mampu menghasilkan 360 pita, yang tersebar ke dalam 71 lokus ISSR dengan tingkat polimorfisme 91.11\%. Berdasarkan koefisien kemiripan dan analisis komponen utama dihasilkan lima kelompok utama pada koefisien kemiripan 0.68 dan uji kecocokan model matrik korelasi (r) penanda molekuler mencapai 0.91 dengan kriteria sangat sesuai, sehingga penanda ISSR tersebut dapat digunakan untuk mengidentifikasi mutan anggrek $\underline{\text { S. plicata. }}$.

Kata kunci: anggrek, iradiasi gamma, marka ISSR, mutan

\section{PENDAHULUAN}

Anggrek Spathoglottis plicata Blume. merupakan salah satu jenis anggrek tanah (terresterial) yang banyak terdapat di Provinsi Bengkulu, dapat tumbuh pada ketinggian 0$1,000 \mathrm{~m} \mathrm{dpl}$. Tempat tumbuh anggrek $S$. plicata di habitat aslinya sangat beragam, mulai dari rawa, tepi tebing dengan semak yang tidak terlalu rimbun dan tidak terlalu tinggi, pada tebing yang baru mengalami longsor, sebagai tanaman invader yang mampu tumbuh pada dinding tebing yang mengalami revegetasi, sampai ke daerah hutan yang tidak terlalu rapat dan masih bisa mendapatkan cahaya matahari langsung. Anggrek ini juga mampu tumbuh pada tanah marjinal dan kurang subur. Biji dapat tumbuh di sepanjang perakaran yang terdapat di permukaan tanah dan pada lumut-lumut yang terdapat di sekitar perakaran (Handoyo dan Prasetya, 2006).

Dari hasil inventarisasi anggrek $S$. plicata di Provinsi Bengkulu oleh Romeida (2012), telah ditemukan aksesi

\footnotetext{
*Penulis untuk korespondensi. e-mail: atrapbt@yahoo.co.id
}

lain anggrek $S$. plicata spesies yang tumbuh endemik di Kabupaten Kepahiang yang mempunyai ciri-ciri berbeda dengan anggrek S. plicata spesies yang sudah ada. Perbedaan utama terdapat pada warna pangkal batang (tangkai daun), tunas dan tangkai bunga utama yang berwarna ungu cerah, warna bunga ungu cerah, kalus (callus) berwarna kuning cerah polos, keping sisi bibir (lateral lobe) berwarna merah cerah dan keping tengah bibir (apical lobe) berwarna ungu cerah dengan bentuk oval dengan sisi samping melengkung ke atas (BALITHI, 2007).

Induksi mutasi dengan berbagai dosis iradiasi sinar Gamma menggunakan ${ }^{60} \mathrm{Co}$ telah dilakukan untuk meningkatkan keragaman genetik anggrek $S$. plicata di PATIR BATAN Jakarta pada tahun 2009. Keberhasilan upaya iradiasi untuk meningkatkan keragaman populasi sangat ditentukan oleh radiosensitivitas genotipe yang diradiasi. Radiosensitivitas dapat diukur berdasarkan nilai $\mathrm{LD}_{50}$ (Lethal dose 50) yaitu dosis yang menyebabkan kematian $50 \%$ populasi tanaman. Beberapa hasil studi induksi mutasi menunjukkan bahwa dosis optimum yang dapat menghasilkan mutan terbanyak umumnya di sekitar 
$\mathrm{LD}_{20}-\mathrm{LD}_{50}$ (Van Harten, 2002). $\quad \mathrm{LD}_{50}$ sudah berhasil didapat pada tanaman jagung (Herison et al., 2008), Thai Tulip (Abdullah et al., 2009) dan stek pucuk anyelir (Aisyah et al., 2009).

Penanda molekuler Inter Simple Sequence Repeats (ISSR) merupakan salah satu penanda dengan motif sekuen berulang. Ada kalanya terdapat penambahan sekuen nukleotida baik pada bagian ujung 3' maupun ujung 5' seperti $(\mathrm{CA})_{8} \mathrm{RG}$ dan $(\mathrm{CA})_{8} \mathrm{RY}$. ISSR adalah fragmen DNA dengan ukuran 100-3,000 bp berlokasi di antara wilayah mikrosatelit, wilayah amplifikasi sekuen DNA yaitu pada inter-SSR bagian flanked genom secara berlawanan pada area yang dekat dengan sekuen berulang (Zietkiewicz et al., 1994).

Keuntungan penggunaan marker ISSR antara lain (1) tidak dipengaruhi musim dan lingkungan (Azrai, 2005), (2) tidak diperlukannya data sekuen terlebih dahulu, (2) hanya membutuhkan 5-50 ng cetakan (template) DNA per reaksi, (3) ISSR tersebar di seluruh genom (4) dapat menghasilkan pola polimorfisme lebih tinggi dari pada RAPD (Guo et al., 2009), (5) menghasilkan polimorfisme pada tingkat kultivar (Lu et al., 2011; Sanjay et al., 2011), (6) bersifat dominan (Kumar, 2009), dan (7) dapat digunakan untuk analisis keragaman genetik dan analisis kekerabatan (Trojanowska dan Bolibok, 2004).

Percobaan ini bertujuan untuk (1) mengidentifikasi keragaman genetik mutan anggrek $S$. plicata (SpBA) hasil iradiasi sinar gamma menggunakan marker ISSR dan (2) mengetahui hubungan filogenetik dan pengelompokan tanaman berdasarkan koefisien kemiripan dan analisis komponen utama.

\section{BAHAN DAN METODE}

Sampel tanaman yang digunakan dalam percobaan ini sebanyak 12 genotipe yang terdiri atas 9 mutan hasil iradiasi sinar gamma di Patir BATAN pada tahun 2009 dan 3 kultivar anggrek $S$. plicata sebagai pembanding (Tabel 1.).
DNA genom total diisolasi dari daun muda menggunakan metode cetyl trimethyl ammonium bromide (CTAB) yang telah dilakukan optimasi oleh Sá et al. (2011), dengan penambahan antioksidan polyvinyl pyrrolidone (PVP), 1,4-dithiothreitol (DTT) dan 2-mercaptoethanol. Primer yang digunakan adalah primer ISSR koleksi Laboratorium Pusat Kajian Buah Tropika LPPM IPB sebanyak 10 primer dengan kode PKBT dan ISSRED yang sudah dilakukan optimasi suhu annealing (Tabel 2).

Polymerase chain reaction (PCR) dilakukan dengan komposisi: DNA $10 \mathrm{ng} \mu \mathrm{L}^{-1}$ sebanyak $5 \mu \mathrm{L}$, primer 10 pmol $\mu \mathrm{L}^{-1}$ sebanyak $5 \mu \mathrm{L}$ dan PCR mix $12.5 \mu \mathrm{L}$, kemudian ditambahkan air bebas ion hingga mencapai volume $25 \mu \mathrm{L}$ menggunakan mesin PCR (Applied Biosystem 2720 thermal cycler). Tahapan siklus PCR dilakukan selama 35 siklus, meliputi pre heat $\left(94^{\circ} \mathrm{C}, 4\right.$ menit), denaturation $\left(94^{\circ} \mathrm{C}, 30\right.$ detik), annealing $\left(36^{\circ} \mathrm{C}-53{ }^{\circ} \mathrm{C}, 30\right.$ detik), extention $\left(72^{\circ} \mathrm{C}\right.$, 1 menit), final extention $\left(72^{\circ} \mathrm{C}, 5\right.$ menit) dan pendinginan $\left(4{ }^{\circ} \mathrm{C}\right.$, sampai tak terhingga).

Data hasil pengamatan molekuler menggunakan marka ISSR, dianalisis menggunakan program NTSYSpc (Numerical Taxonomy and Multivariate Analysis) versi 2.02i (Rohlf, 1998). Pengamatan pola pita DNA yang dihasilkan menggunakan marka ISSR, setelah dilakukan elektroforesis untuk memisahkan lokus yang memiliki ukuran yang berbeda, selanjutnya diberi nilai skor 1 apabila muncul pita dan nilai skor 0 apabila tidak muncul pita (Liu et al., 2006). Pengamatan pita DNA berdasarkan konsistensi ketebalan pita DNA yang diamati. Angka biner dianalisis menggunakan program NTSYS-pc versi 2.02i. Metode pengelompokan menggunakan koefisien dice dari Similarity for Qualitative Data (SIMQUAL) dan Sequential Agglomerative Hierarchical and Nested (SAHN) - Unweighted pair-group method arithmatic average (UPGMA). Hasil pengelompokan berupa dendrogram yang memvisualisasikan hubungan genetik antar mutan dan tanaman pembanding yang digunakan. Tingkat keselarasan pengelompokan ditentukan oleh nilai goodness of fit yaitu

Tabel 1. Daftar mutan anggrek S. plicata dan pembandingnya yang dikarakterisasi secara morfologi dan molekuler (ISSR)

\begin{tabular}{lccc}
\hline Kode sampel & Asal tanaman & $\begin{array}{c}\text { Stabil sampai } \\
\text { tanaman }\end{array}$ & Keterangan \\
\hline SpBA & Kepahiang Bengkulu & M1V6 & S. plicata batang ungu, bunga ungu (wild type) \\
Mutan1 (1SpBA50) & SpBA & M1V6 & Dosis Iradiasi 50 Gy \\
Mutan 2 (2SpBA70) & SpBA & M1V3 & Dosis Iradiasi 70 Gy \\
Mutan 3 (3SpBA50) & SpBA & M1V3 & Dosis Iradiasi 50 Gy \\
Mutan 4 (4SpBA60) & SpBA & M1V6 & Dosis Iradiasi 60 Gy \\
Mutan 5 (5SpBA100) & SpBA & M1V2 & Dosis Iradiasi 100 Gy \\
Mutan 6 (6SpBA50) & SpBA & M1V2 & Dosis Iradiasi 50 Gy \\
Mutan 7 (7SpBA40) & SpBA & M1V2 & Dosis Iradiasi 40 Gy \\
Mutan 8 (8SpBA30) & SpBA & M1V2 & Dosis Iradiasi 30 Gy \\
Mutan 9 (9SpBA60) & SpBA & M1V2 & Dosis Iradiasi 60 Gy \\
SO4 & Balithi Segunung & M1V6 & S. plicata cv. Alba batang hijau bunga putih \\
SpBH & Kepahiang Bengkulu & M1V6 & S. plicata batang hijau bunga ungu \\
\hline
\end{tabular}


kesesuaian antara nilai koefisien kemiripan (SM) dengan kriteria sangat sesuai $(\mathrm{r} \geq 0.9)$, sesuai $(0.8 \leq \mathrm{r}<0.9)$, tidak sesuai $(0.7 \leq \mathrm{r}<0.8)$ dan sangat tidak sesuai $(\mathrm{r}<0.7)$ (Soltis et al., 1998). Analisis komponen utama dianalisis menggunakan program MINITAB. Hasil analisis berupa plot dua dimensi dan karakter pendukung pengelompokan.

\section{HASIL DAN PEMBAHASAN}

\section{Analisis Penanda Molekuler ISSR}

Primer yang mampu memperlihatkan kedekatan hubungan antara mutan anggrek $S$. plicata dan pembandingnya ditunjukkan dengan munculnya pola pita yang polimorfik pada jarak yang sama menggunakan 10 primer ISSR (PKBT 2, PKBT 3, PKBT 4, PKBT 6, PKBT 7, PKBT 8, PKBT 9, ISSRED 12, ISSRED 14 dan ISSRED 20).

Polimorfisme pola pita yang dihasilkan dari 10 primer ISSR menunjukkan keberagaman yang sangat tinggi hingga mencapai $90.14 \%$. Pola pita monomorfik hanya $9.86 \%$ yang dihasilkan dari primer PKBT2f ukuran 400 pb, primer PKBT3g ukuran $250 \mathrm{pb}$, primer PKBT6i ukuran $250 \mathrm{pb}$, primer PKBT7f ukuran $250 \mathrm{pb}$, primer PKBT9b ukuran $800 \mathrm{pb}$, primer ISSRED14d ukuran $700 \mathrm{pb}$ dan primer ISSRED20e ukuran $850 \mathrm{pb}$. Jumlah lokus yang mampu dihasilkan dengan menggunakan 10 primer ISSR berkisar antara 6-9 lokus per primer. Total hasil amplifikasi mampu menampilkan 71 lokus, yang terdiri atas 64 lokus (90.14\%) yang tersusun dari pola pita polimormik dan 7 lokus $(9.86 \%)$ tersusun dari pola pita monomorfik (Tabel 2).

Jumlah lokus dihitung berdasarkan jumlah pita yang muncul pada jarak migrasi fragmen DNA tertentu, sesuai dengan besar atau kecilnya fragmen DNA. Fragmen DNA yang besar akan bergerak lebih lambat, sementara fragmen DNA yang kecil akan bergerak lebih cepat. Pita-pita DNA yang muncul pada sampel DNA yang dianalisis sangat erat hubungannya dengan cocok atau tidaknya primer ISSR yang digunakan untuk mengamplifikasi DNA genom mutan anggrek $S$. plicata dan pembandingnya. Pita hanya akan muncul bila urutan sekuen primer cocok dengan urutan basa mikrosatelit yang terdapat tanaman sampel, apabila motif primer yang digunakan tidak cocok dengan motif urutan basa DNA yang terdapat DNA genom maka pita tidak akan muncul (Wang et al., 2009).

\section{Analisis Cluster Berdasarkan pada Profil Pola Pita Penanda ISSR}

Analisis penanda molekuler DNA diperlukan untuk mengevaluasi keragaman genetik dan hubungan kekerabatan di antara tanaman mutan, tanaman mutan dengan tipe liarnya dan di antara kultivar anggrek $S$. plicata yang digunakan sebagai pembanding. Marka molekuler mampu menunjukkan pola perubahan sampai pada level genetik (DNA) jika dibandingkan dengan karakter morfologi yang dipengaruhi oleh faktor genetik dan lingkungan.

Berdasarkan hasil analisis data biner skor pita DNA menggunakan program NTSYS, diperoleh 5 kelompok tanaman pada koefisien kemiripan 0.68 yaitu kelompok 1, merupakan kelompok tanaman anggrek spesies yang digunakan sebagai sumber bahan iradiasi sinar gamma yaitu anggrek $S$. plicata batang ungu berbunga ungu cerah (SpBA), anggrek S. plicata yang digunakan sebagai pembanding yaitu $S$. plicata batang hijau berbunga ungu (SpBH) dan S. plicata cv. Alba batang hijau berbunga putih (S04) dengan koefisien kemiripan berkisar antara 0.691.00. Kelompok 2 terdiri atas mutan 3 dengan koefisien kemiripan 0.95. Kelompok 3, merupakan kelompok tanaman mutan hasil iradiasi berbagai dosis iradiasi sinar gamma yang meliputi mutan 1 , mutan 2 , mutan 5 , mutan 6 , mutan 7 dan mutan 8 dengan koefisien kemiripan sebesar 0.61 . Kelompok 4 terdiri atas mutan 9 dengan koefisien kemiripannya sebesar 0.61. Kelompok 5 terdiri atas mutan 4 dengan koefisien kemiripannya hanya 0.48. (Gambar 1). Pengelompokan tersebut sangat sesuai menggambarkan

Tabel 2. Rekapitulasi jumlah pita DNA hasil amplifikasi menggunakan 10 primer ISSR anggrek S. plicata dan mutannya

\begin{tabular}{|c|c|c|c|c|c|c|}
\hline Nama primer & Susunan basa & Suhu annealing & Jumlah pita & Jumlah lokus & $\begin{array}{c}\text { Lokus } \\
\text { polimorfik }\end{array}$ & $\begin{array}{c}\text { Lokus } \\
\text { monomorfik }\end{array}$ \\
\hline PKBT 2 & $(\mathrm{AC}) 8 \mathrm{TT}$ & $53{ }^{\circ} \mathrm{C}$ & 33 & 7 & 6 & 1 \\
\hline PKBT 3 & $(\mathrm{AG}) 8 \mathrm{~T}$ & $53{ }^{\circ} \mathrm{C}$ & 35 & 7 & 6 & 1 \\
\hline PKBT 4 & $(\mathrm{AG}) 8 \mathrm{AA}$ & $53{ }^{\circ} \mathrm{C}$ & 28 & 6 & 6 & 0 \\
\hline PKBT 6 & $(\mathrm{AG}) 8 \mathrm{TT}$ & $53{ }^{\circ} \mathrm{C}$ & 61 & 9 & 8 & 1 \\
\hline PKBT 7 & (GA)9 A & $54{ }^{\circ} \mathrm{C}$ & 33 & 6 & 5 & 1 \\
\hline PKBT 8 & (GA)9 C & $54{ }^{\circ} \mathrm{C}$ & 19 & 6 & 6 & 0 \\
\hline PKBT 9 & (GA)9T & $54{ }^{\circ} \mathrm{C}$ & 45 & 6 & 5 & 1 \\
\hline ISSRED 12 & $(\mathrm{AGAC}) 4$ & $36^{\circ} \mathrm{C}$ & 27 & 6 & 6 & 0 \\
\hline ISSRED 14 & $(\mathrm{GAC}) 5$ & $48^{\circ} \mathrm{C}$ & 40 & 9 & 8 & 1 \\
\hline ISSRED 20 & $(\mathrm{TCC}) 5 \mathrm{~A}$ & $48^{\circ} \mathrm{C}$ & 39 & 9 & 8 & 1 \\
\hline Total & & & 360 & 71 & $\begin{array}{c}64 \\
(90.14 \%)\end{array}$ & $\begin{array}{c}7 \\
(9.86 \%)\end{array}$ \\
\hline
\end{tabular}




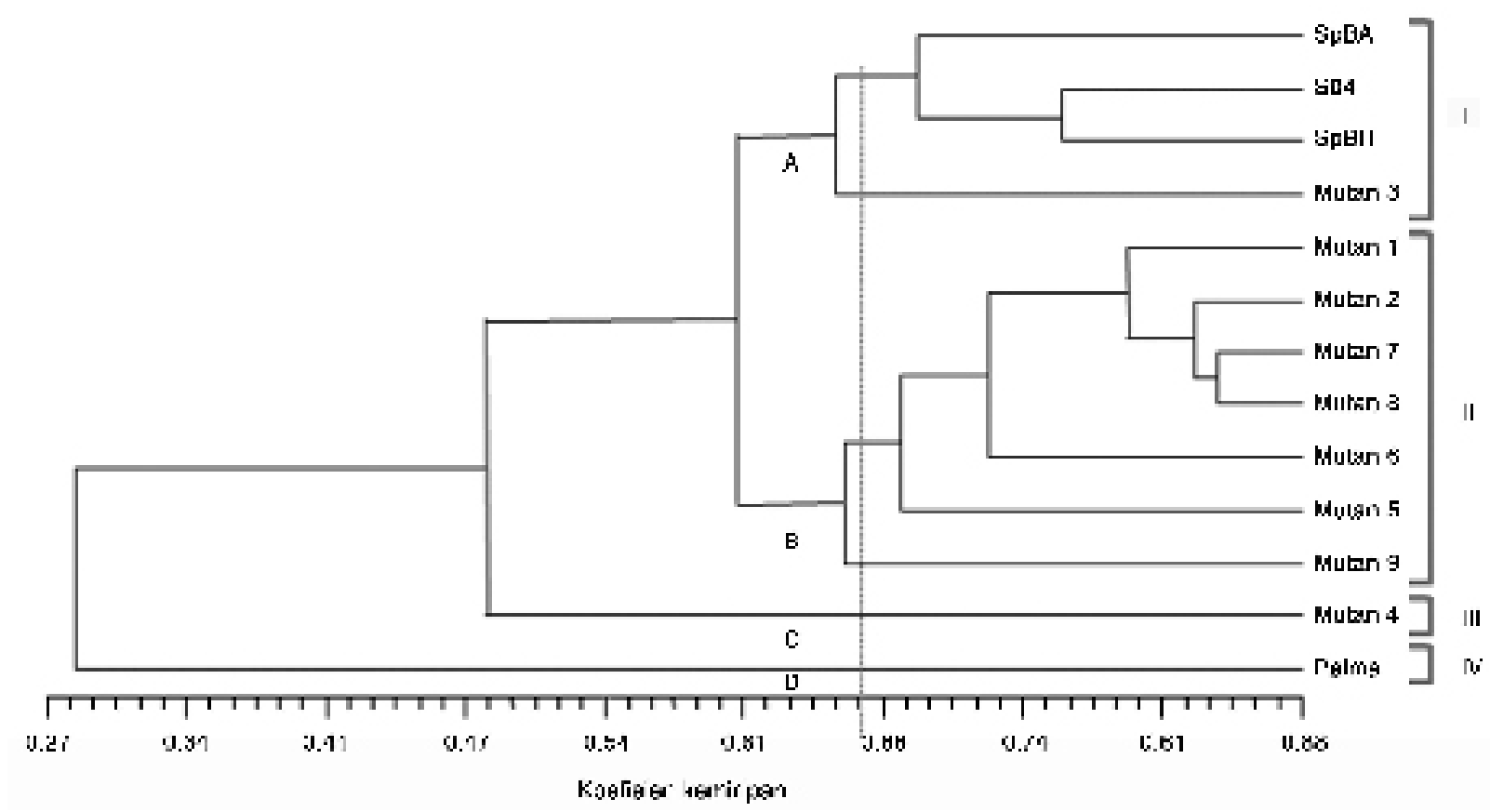

Gambar 1. Dendrogram analisis kluster berdasarkan karakter molekuler ISSR 9 mutan anggrek S. plicata dan 3 pembandingnya pada koefisien kemiripan 0.68

kedekatan hubungan diantara kultivar tanaman anggrek $S$. plicata, antara tanaman tipe liar anggrek S. plicata dengan tanaman mutan hasil iradiasi berbagai dosis sinar gamma dan antara tanaman mutan anggrek $S$. plicata hasil iradiasi sinar gamma. Nilai goodness of fit matrik korelasi (r) penanda molekuler mencapai 0.91 dengan kriteria sangat sesuai.

Koefisien kemiripan $\geq 0.68$ antara tanaman anggrek spesies dengan mutannya menandakan bahwa terjadi perubahan atau perbedaan sebesar $38 \%$, sehingga secara morfologi dapat dibedakan dengan jelas perbedaan antara mutan dengan tipe liarnya. Perbedaan morfologi utama yang terjadi pada tanaman mutannya adalah perubahan warna bunga, yang dihasilkan pada mutan 1, mutan 2, mutan 3 , mutan 7 dan mutan 9 . Warna bunga yang didapatkan pada mutan-mutan anggrek $S$. plicata berkisar mulai dari warna pink sangat muda (mutan 2), gradasi warna pink cerah dengan kuning (mutan 1), warna bunga pink muda dengan bintik-bintik pink tua (mutan 3), pink muda (mutan 9), serta warna sepal pink muda yang dikombinasikan dengan warna ungu cerah pada petalnya (mutan 7). Perubahan bentuk petal bunga dari petal yang berbentuk rata menjadi bergelombang (mutan 8), serta terjadi penyatuan sepal lateral (mutan 9) (Gambar 2).

Perubahan yang sangat besar terjadi pada mutan 4 dengan koefisien kemiripan hanya 0.48 karena terjadi perubahan warna bunga (petal dan sepal) menjadi kuning cerah, tinggi tanaman berkurang sampai $60 \%$, dan ukuran daun berkurang sampai $74.6 \%$, sehingga dalam analisis clustering dengan SAHN-UPGMA maupun analisis komponen utama terlihat terjadi pemisahan dengan kelompok mutan lainnya.

Hasil percobaan ini sejalan dengan beberapa percobaan yang telah dilaporkan pada beberapa anggrek dari genus yang lain, seperti yang dilaporkan oleh $\mathrm{Lu}$ et al. (2011), bahwa penggunaan marka ISSR ternyata juga berhasil mengelompokkan keragaman genetik 151 kultivar anggrek Cymbidium sinence menjadi 7 kelompok utama. Shen et al. (2006), juga melaporkan bahwa penanda sidik jari molekuler ISSR juga telah berhasil digunakan untuk mengidentifikasi delapan populasi Dendrobium officinale menggunakan 10 primer ISSR hasil seleksi dari 76 primer ISSR.

Pengelompokan Mutan Anggrek $\underline{S}$. plicata dan Pembandingnya Berdasarkan Nilai Analisis Komponen Utama Marka Molekuler (ISSR)

Pengelompokan aksesi yang memiliki kemiripan berdasarkan karakter molekuler disajikan menggunakan gambar dua dimensi (biplot) melalui pengukuran analisis komponen utama. Data karakter yang dapat digambarkan melalui hasil analisis komponen utama menggunakan 10 primer ISSR hanya sebesar 70\% dari keseluruhan data.

Karakter-karakter yang mempengaruhi pembentukan pengelompokan berdasarkan nilai akar ciri (Eigenvalue) komponen utama ada sejumlah 8 karakter, terdiri dari 3 karakter komponen utama ke-1 (PC1), 2 karakter komponen utama ke-2 (PC2), 1 karakter komponen utama ke-3 (PC3), 1 karakter komponen utama ke-4 (PC4) dan 1 karakter komponen utama ke-5 (PC5). Primer ISSR PKBT6h dengan posisi pita $350 \mathrm{pb}$, memiliki nilai komponen utama yang tertinggi 0.340 . Tanaman yang memiliki pita primer PKBT6h pada posisi $350 \mathrm{pb}$ adalah SpBA, mutan 1, mutan 2 , mutan 3, mutan 4, mutan 6, mutan 7 dan mutan 8. Primer ISSR yang mampu menyusun nilai komponen utama terbanyak adalah Primer ISSR PKBT 4 dengan posisi pita $500 \mathrm{pb}$ terdapat pada tanaman SpBA, mutan 3, mutan 6, S04 dan SpBH dan posisi pita 1,000 pb yang terdapat pada 


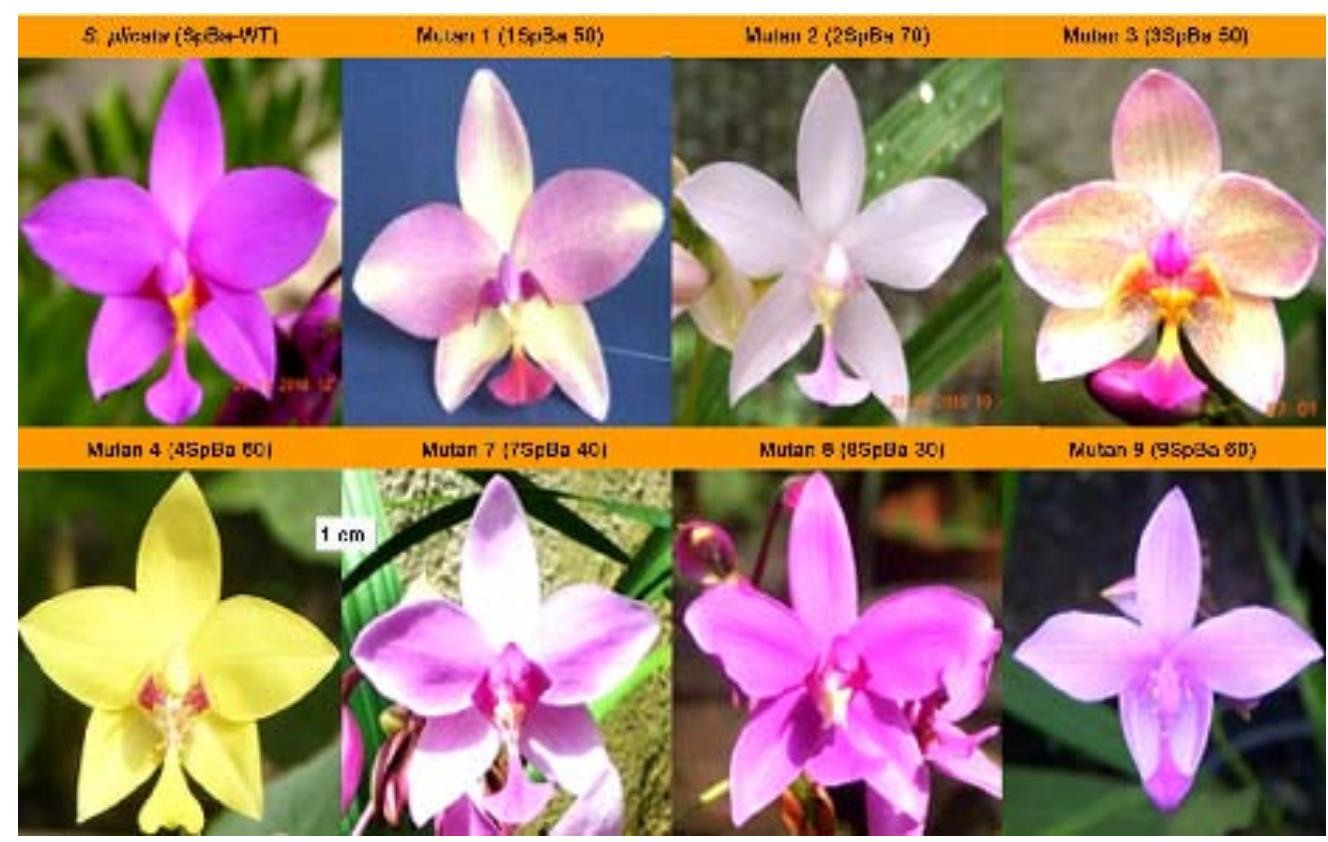

Gambar 2. Perbedaan bentuk dan warna bunga anggrek S. plicata dan 7 mutan hasil iradiasi sinar gamma

tanaman SpBA, mutan 1, mutan 3, mutan 6, S04 dan SpBH (Tabel 3, Gambar 3).

Hasil analisis komponen utama yang dapat digambarkan ke dalam gambar dua dimensi (biplot), menggunakan penanda molekuler anggrek $S$. plicata beserta mutannya membentuk 5 kelompok yaitu kelompok 1 terdiri atas SpBA, S04, SpBH. Kelompok 2 terdiri atas mutan 3. Kelompok 3 terdiri atas mutan 1, mutan 2, mutan 5, mutan 6 , mutan 7 dan mutan 8 . Kelompok 4 terdiri atas mutan 9. Kelompok 5 terdiri atas mutan 4 (Gambar 4).

Perbedaan pola pita antar mutan $S$. plicata maupun dengan tipe liarnya, bukan berarti lokus ISSR tersebut merujuk langsung pada perbedaan bentuk dan warna bunga tanaman mutan anggrek $S$. plicata. Walaupun demikian, pengelompokan berdasarkan marka molekuler ISSR setelah dianalisis dengan metode SAHN-UPGMA dan analisis komponen utama ternyata telah mampu dengan tegas menunjukkan keragaman genetik yang terjadi pada beberapa mutan anggrek $S$. plicata hasil iradiasi sinar gamma dan telah terjadi perbedaan tanaman sampai pada level genetik, sehingga semua mutan yang dihasilkan melalui induksi mutasi dengan iradiasi sinar gamma sudah dapat dikelompokkan sebagai tanaman mutan.

Marka ISSR sudah banyak digunakan untuk mengidentifikasi spesies, kultivar ataupun populasi suatu spesies yang mirip dengan level variasi genetik yang rendah, dan sangat berguna sebagai alat pendeteksi keragaman genetik suatu spesies tanaman yang mempunyai variasi genetik yang sangat luas. Penggunaan marka ISSR telah berhasil mendeteksi keragaman genetik 31 spesies anggrek Dendrobium (Wang et al., 2009), keragaman genetik Scutellaria baicalensis (Guo et al., 2009), keragaman genetik di antara populasi Rynchostylis retusa anggrek epifit dari Goa (Parab dan Khrisnan, 2008), dan menghasilkan sidik jari molekuler penanda populasi anggrek Dendrobium officinale KIMURA et MIGO (Shen et al., 2006).

Tabel 3. Karakter pita DNA pembentuk komponen utama berdasarkan marka ISSR

\begin{tabular}{lclll}
\hline $\begin{array}{l}\text { Komponen } \\
\text { utama }\end{array}$ & $\begin{array}{l}\text { Jumlah } \\
\text { karakter }\end{array}$ & Jenis karakter & Nilai & Terdapat pada tanaman \\
\hline PC1 & 3 & ISSRED14a (1,600 bp) & 0.244 & SpBA, Mutan 3, S04, SpBH \\
& & PKBT7a (1,600 bp) & 0.271 & Mutan 3, Mutan 4, S04, SpBH \\
& & PKBT4e (500 bp) & 0.234 & SpBA, Mutan 3, Mutan 6, S04, SpBH \\
PC2 & 2 & PKBT4b (1,000 bp) & -0.225 & SpBA, Mutan1, Mutan 3, Mutan 6,S04, SpBH \\
& & PKBT7c (1,000 bp) & -0.211 & SpBA, Mutan 1, Mutan 3, Mutan 6, Mutan 9, S04, SpBA \\
PC3 & 1 & ISSRED14f (500 bp) & 0.312 & Mutan 3, Mutan 4, Mutan 6, Mutan 7 \\
PC4 & 1 & PKBT6h (350 bp) & 0.340 & SpBA, Mutan 1, Mutan 2, Mutan 3, Mutan 4, Mutan 6, \\
& & & & Mutan 7, Mutan 8 \\
PC5 & 1 & ISSERD12b (1,200 bp) & 0.28 & SpBA, Mutan 6, Mutan 7, Mutan 8, Mutan 9 \\
\hline
\end{tabular}




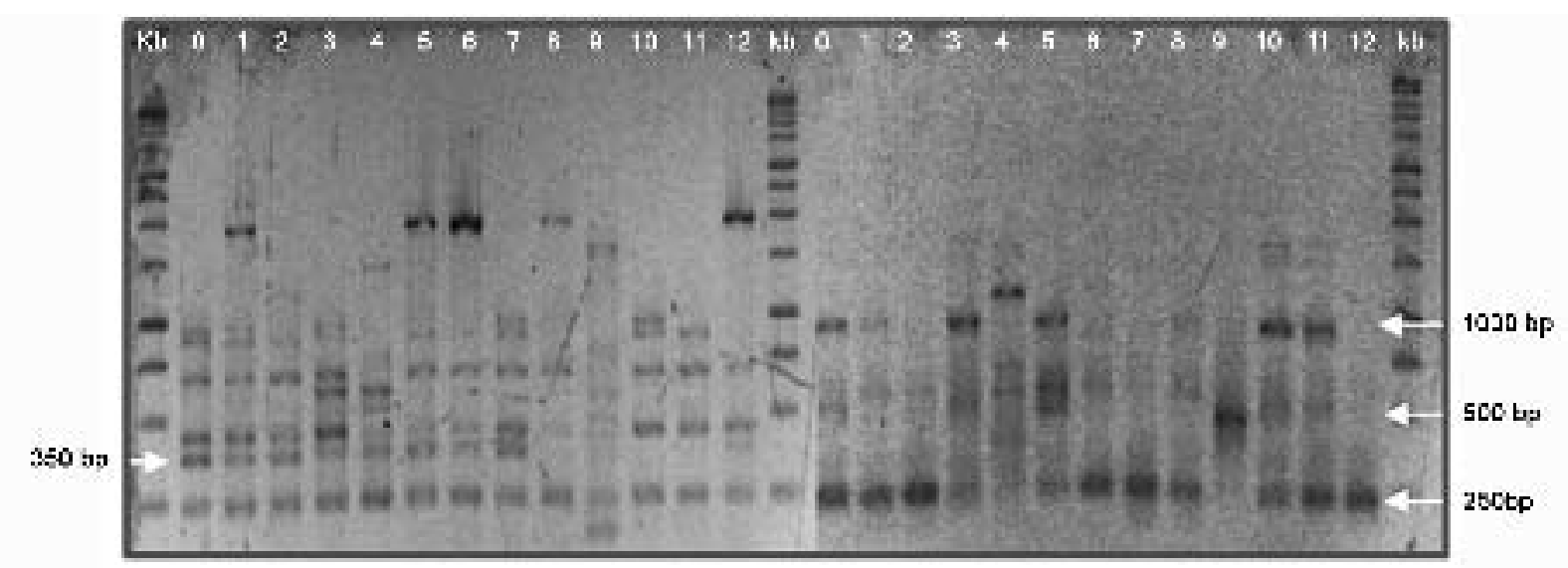

Gambar 3. Karakter pola pita DNA 13 genotipe anggrek $S$. plicata hasil amplifikasi menggunakan primer ISSR PKBT6 (kiri) dan PKBT 4 (kanan). $(\mathrm{Kb})=$ ladder $1 \mathrm{~kb} ;(0,11,12)=\mathrm{SpBa}, \mathrm{S} 04, \mathrm{SpBH} ;(1-9)=$ mutan SpBa hasil iradiasi sinar gamma; $(10)=$ Palma

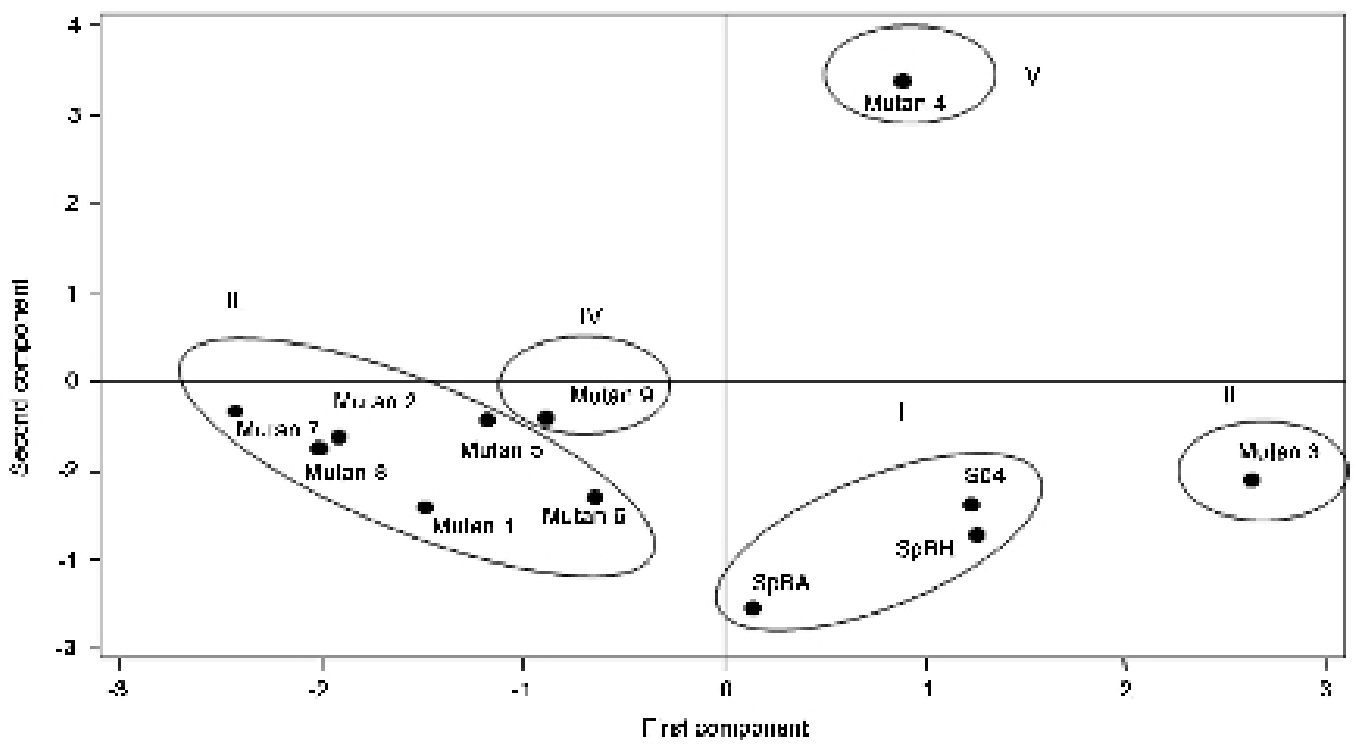

Gambar 4. Hasil analisis komponen utama yang digambarkan ke dalam gambar dua dimensi, menggunakan penanda molekuler ISSR mutan anggrek S. plicata dan pembandingnya

\section{KESIMPULAN}

Iradiasi sinar gamma dapat menginduksi keragaman genetik pada anggrek $S$. plicata, sehingga sangat berperan dalam pemuliaan tanaman anggrek $S$. plicata terutama dalam meningkatkan keragaman genetiknya. Polimorfisme pola pita DNA yang dihasilkan dari 10 primer ISSR menunjukkan keberagaman yang sangat tinggi hingga mencapai 90.14\%. Hasil analisis klustering pola pita ISSR menggunakan metode UPGMA pada koefisien kemiripan 0.68 dan analisis komponen utama terhadap 9 mutan anggrek $S$. plicata dan 3 pembandingnya mampu dibedakan dengan tegas menjadi 5 kelompok utama dengan nilai goodness of fit matrik korelasi (r) penanda molekuler mencapai 0.91 (sangat sesuai).

\section{UCAPAN TERIMA KASIH}

Terima kasih disampaikan kepada Dirjen DIKTI, yang telah mendanai penelitian ini melalui Penelitian Hibah
Bersaing T.A. 2011-2012 tahun kedua dan kepada PATIR BATAN Jakarta yang telah membantu proses Iradiasi sinar gamma.

\section{DAFTAR PUSTAKA}

Abdullah, T.L, J. Endan, M. Nazir. 2009. Changes in flower development, chlorophyll mutation and alteration in plant morphology of Curcuma alismatifolia by gamma irradiation. Am. J. Appl. Sci. 6:1436-1439.

Aisyah, S.I., H. Aswidinnor, A. Saefuddin. 2009. Induksi mutasi stek pucuk Anyelir (Dianthus caryophyllus Linn.) melalui iradiasi sinar gamma. J. Agron. Indonesia 37:62-70.

Azrai, M. 2005. Pemanfaatan marka molekuler dalam proses seleksi pemuliaan tanaman. J. AgroBiogen $1: 26-37$. 
[BALITHI] Balai Penelitian Tanaman Hias. 2007. Panduan Karakterisasi Tanaman Anggrek. Balithi-Segunung, Bogor.

Guo, H.B., K.Y. Huang, T.S. Zhou, Q.H. Wu, Y.J.Zhang, Z.S. Liang. 2009. DNA isolation, optimization of ISSRPCR system and primers screening of Scutellaria baicalensis. J. Med. Plant Res. 3:898-901.

Handoyo, F., R. Prasetya. 2006. Native Orchids of Indonesia. Indonesian Orchid Society of Jakarta, Jakarta.

Herison, C., Rustikawati, S.H. Sutjahjo, S.I. Aisyah. 2008. Induksi mutasi melalui iradiasi sinar gamma terhadap benih untuk meningkatkan keragaman populasi dasar jagung (Zea mays L.). J. Akta Agrosia 11:57-61.

Kumar, P. 2009. Potential of molecular markers in plant biotechnology. Plant Omics J. 2:141-162.

Liu, J.J., A.K.M. Ekramoddoullah, R. Hunt, A. Zainal. 2006. Identification and characterization of RAPD markers linked to a major gene $(\mathrm{Cr} 2)$ for resistant to Cronartium ribicola (Fish.) in Pinus monticola (D.Don.). Phytopathol. 96:395-399.

Lu, J, X. Hu, J. Liu, H. Wang. 2011. Genetic diversity and population structure of 151Cymbidium sinense cultivars. J. Hortic. For. 3:104-114.

Parab, G.V., S. Khrisnan, 2008. Assessment of genetic variation among populations Rynchostylis retusa, an epiphitic orchid from Goa, India using ISSR and RAPD markers. Indian J. Biotechnol. 7:313-319.

Rohlf, F.J. 1998. NTSYS-PC. Numerical Taxonomy and Multivariate Analysis System, Version 2,00. Exeter Software, Setauket, New York.

Romeida, A. 2012. Induksi mutasi dengan iradiasi sinar gamma untuk pengembangan klon unggul anggrek Spathoglottis plicata Blume. aksesi Bengkulu. Disertasi. Sekolah Pascasarjana. Institut Pertanian Bogor. Bogor.
Sá, O, J. A. Pereira, P. Baptista. 2011. Optimization of DNA extraction for RAPD and ISSR analysis of Arbutus unedo L. leaves. Int. J. Mol. Sci. 12: 4156-4164.

Sanjay, L.S., K.N. Mistry, S.D. Shah, R.Thaker, P.B. Vaidya. 2011. Genetic diversity assessment in nine cultivars of Catharanthus roseus from Central Gujarat (India) through RAPD, ISSR and SSR markers. J. Res. Biol. 8:667-675.

Shen, J., X. Ding, D. Liu, G. Ding, J. He, X. Li, F. Tang, B. Chu. 2006. Inter-simple Sequence Repeats (ISSR) molecular fingerprinting markers for authenticating populations of Dendrobium officinale KIMURA et MIGO. Biol. Pharm. Bull. 29:420-422.

Soltis, E.D., S.P. Soltis, J.F. Doyle. 1998. Contributions of PCR-Based Methods to Plant Systematics and Evolution Biology. Molecular Systematics of Plants II DNA Sequencing. Kluwer Academic Publishers, Massachussets.

Trojanowska M.R., H. Bolibok. 2004. Characteristics and comparison of three classes of microsatellite-based markers and their application in plants. Cellular Mol. Biol. Lett. 9:221-238.

Van Harten A.M. 2002. Mutation breeding of vegetatively propagated ornamentals. p. 105-129. In A Vainstein $(E d$.$) . Breeding for Ornamentals: Classical and$ Molecular Approaches. Kluwer Academic Press., Boston.

Wang, H.Z., S.G. Feng. J.J. Lu, N.N. Shi, J.J. Liu. 2009. Phylogenetic study and molecular identification of 31 Dendrobium species using inter-simpel sequent repeat (ISSR) markers. SciHort. 122:440-447.

Zietkiewicz, E., A. Rafalski, D. Labuda. 1994. Genome fingerprinting by simple sequence repeat (SSR) anchored polymerase chain reaction amplification. Genomics 20:176-183. 